\title{
DEAF DISABILITY AND EMPLOYMENT IN BRASILIA: PROFESSIONAL OPPORTUNITY IN EVENT MARKET
}

\author{
Elane Pereira da Silva Oliveiraa; \\ Letícia Bianca Barros de Moraes Limab
}

\begin{abstract}
This research paper's main objective is to analyze the employability for people with deaf disability in Brasilia, as a professional opportunity in the event market. The research highlights the variety of jobs, which could be performed by people with deaf disability, considering the event type proposed. The specific objectives were bounded as follows: to conceptualize the events and characterize the market employability; to identify and to present the placements inside the events for deaf disability. In order to reach those objectives, qualitative research has been performed involving a group of seven people with deaf disability, with almost none experience on Event Management tasks and six event management producers in Brasilia. In order to achieve the proposed objectives of this research, questionnaires were applied with ten objective questions and a subjective one via email with the questionnaire in Word to the event producers, and questionnaires for the deaf were applied in Libras via video and also via google forms, containing sixteen objective questions, which were submitted to data and discourse analysis using the Iramuteq software. Thoroughly observing the answers from both groups, a large opportunity to increase the job market in the event management areas in Brasilia has been identified. .
\end{abstract}

\section{Palavras-chave}

Employability

Deaf

Accessibility 


\section{INTRODUCTION}

IThe demands of the labor market in Brazil, in most of the cases, relies on employing workers with extensive experiences on new technologies and performing functions in addition to those assigned to them. In this context, it is possible to verify the complexities of inclusion that organizations usually present. These complexities are also extended to the deaf community regarding those demands of the labor market. According to (2008) "... it is necessary to clarify and understand that the deaf are different on language and cultural skills, therefore they are not disabled, but citizens with all right reserved". The decree 5.626/05 Article 2nd, consider a deaf person all of the ones with hearing losses but understand and interact through visual contact and using Sign Language - Brazilian Sign Language (Brasil, 2005).

According to data from BIGS - Brazilian Institute of Geography and Statistics (2000), there are 454 million people with some type of disability in Brazil, and in 2010, according to the Demographic Census, the Federal District had 573,805 people with disabilities, $22.23 \%$ of the total population. Among the reported deficiencies, the one that appears in greater proportion in the Federal District is visual (63.71\%), followed by motor (18.02\%), hearing (14.41\%) and mental/ intellectual (3.85) \%) (BIGS, 2010).

Through these data, there are some distortions and discrimination by the deaf in the majority hearing society, when the latter mistakenly believe that the deaf are deficient and underestimate the efficiency of this professional in the job market, when in reality they face communication difficulties, that in fact hinders performance and coexistence in the work environment, however within the deaf community, they recognize and dialogue, as there are no barriers in communication revealing mainly that they are capable of developing other activities.

The motivation for this research started during the first semester of the Event Management course where one of the researchers found herself with a deaf student. Using the observation and learning, she was able to notice the fragility and limitation of the deaf universe. The awakening interest to the research arose on how those limitations could imply that future deaf professionals. At the same time, the questioning about what abilities could be applied by that same professional in the Event Management sector has motivated the researchers. Thus, some guiding questions come with these findings, such as: is it possible for the deaf to develop all functions in a given event? Is there a demand for deaf professionals by companies or event producers? How is the integration of deaf and hearing people made within organizations? Is it possible to hire Libras translators/interpreters in companies? Can events admit deaf workers? Have companies been preparing to receive the deaf, learning Libras?

In order to answer these concerns, the central objective of this research was set: to analyze the employability of the deaf in Brasilia as an opportunity to access the event market.

\section{LITERATURE REVIEW}

\section{Event Market in Brazil}

The events of tourism - shows, congresses, exhibitions, and many other business models - have contributed to consolidate event activities as inducting segment to develop the market regionally. They have been helping to create business opportunities, jobs, and income for those who participate in this destination. (MTUR, 2019).

To describe the event sector importance, to the touristic scenario and the benefits of practicing event activities, which involves the market by itself, it is prior demand to understand the concept and characteristics that the events have.

According to Zitta (2009), all event starts from fantasy, initially, reaching the idealization in the implementation of ideas and projects, seeking to attract the target audience". When assimilating and interpreting this knowledge, it can be said that an event, in general, is characterized as "any event that goes beyond routine, always programmed to gather a group of people" (SENAC, 2000).

This means it is a temporal photograph of a certain moment where certain public gathers, eventually, to celebrate, discuss or resonate a fact, theme, or frequent or non-frequent ideas. In other words, everything that happens, any action that involves people or the environment in which these people are inserted is an event.

Given the above, it should be considered that according to such statement, it is determined that there will only be an event if there is an eventuality, that is, a reason and "Its main characteristic is to provide an extraordinary occasion to meet people, with the specific purpose, which constitutes the main "theme" and justifies its realization" (Giacaglia, 2006).

According to ABEOC (2013), Brazil hosted 590 thousand events in 2013, 95\% of the national and half held in the Southeast. In all, they had the participation of 202.2 million people who spent, on average, $\mathrm{R} \$ 161.80$ (which added up to expenses of $\mathrm{R} \$ 99.3$ billion). The revenue of event organizers increased 18 times this year, compared to 2001 (ABEOC, 2013). Also in accordance with ABEOC (2013), 'Sociocultural events' were the most frequent type of event in the year 2013 in Brazil, in different spaces, followed by 'Meetings', 
'Conventions' and 'Congresses'. Also noteworthy is the important participation of 'Mixed events', expressing a growth trend in relation to the study carried out in 2001 (ABEOC,2013).

\section{The deaf and their language: initial considerations}

Data from the 2010 Census of the Brazilian Institute of Geography and Statistics (BIGS) indicate that about 2.2 million Brazilians have hearing loss in severe situations; and, among these, 344,200 are deaf and speak Libras. In 2002, through Law No. 10,436, the method of communication through Libras started to be recognized as a legal means of communication and expression.

In the beginning, the Sign Language was originated from the French Sign Language system, and according to Gesser (2009), the structure of Sign Language is constituted by matching parameters that combine. Quadros \& Karnopp (2004) describe in their language research that hands configuration, articulation point, localization, and movement prevail as "minimal units (phonemes) that build the morphemes in Sign Language. According to Gesser, about the fourth parameter of sign language.

Starting from the 1970s, linguists Robbin Battison (1974), Edward S. Klima \& Ursulla Bellugi (1979) conducted more in-depth studies on ASL grammar, specifically on phonological aspects, describing the fourth parameter: palm orientation of the hand $(O)$ (GESSER, 2009, p. 14). In 2005, Decree no. 5,626 / 05, Art. 3, which determines the insertion of Libras as a mandatory curricular discipline in teacher training courses for the exercise of teaching, at the secondary and higher levels, took place.

In cultural terms, deafness is not considered just a physiological condition, it is built by its own culture. The sense of deaf culture is stronger among those who use this language. This is because the deaf use their linguistic difference as a way of raising self-esteem and empowering their achievements. For deaf people, the terminology "hearing impaired" is rejected because it defines the deaf according to their ability or absence of hearing and not the presence of linguistic culture of their own (STROBEL, 2008).

According to Goss (2003) culturally, deaf people prefer to see their deafness positively as a different culture, rather than disability, just as the medical and professional community often consider deafness to be a disease. People who accept the medical community's label of "deaf people with disabilities" are not considered culturally deaf.

\section{The deaf and professions in Brasilia}

Although the deaf are hired for operational functions in several professional areas, most of the time companies propose to hire, due to the requirements that Federal Law No. 8.213 / 91 establishes, that is, it ensures the insertion of these people in the labor market. job. Therefore, it appears that companies are not yet adapted to include the deaf in their staff.

As per Carvalho (2012), the companies need to be prepared, not enough hire, but the support that allows the deaf to develop functions. A possibility would be the producer/employer to provide Sign Language to all employees, so that would be promoting not only the minimal communication between staff but mainly the autonomy that many of the deaf search and need.

According to Carvalho (2012) companies need to be prepared, it is not enough just to employ, but to provide the support that contributes to the deaf perform the functions. One possibility would be for the producer/employer to provide a Libras course for all employees, thus promoting not only the minimum communication among their collaborators but mainly the autonomy that many deaf people seek and need.

As stated by Oliveira (2007, p.201), there is still a mistaken thought about the deaf, where they consider themselves incapable to perform functions, when in reality, they did not have adequate communication to perform their actions.

In the view of Pastore (2000), it is "clear the fragility" of the policies imposed by the law on the deaf and disabled people in the labor market, who are stigmatized as disabled for the deaf and sick for the Disabled by employers and society, which define them. Even so, it is necessary to deconstruct this stigma imposed on the deaf by a majority listening society, to break this paradigm so that this oppressed people can enter for decades, through an archaic and widespread thought that the deaf are incapable and deficient when in reality they are very different meanings.

In this sense, the laws are aimed at the educational and professional spheres, but for there to be efficiency in compliance, it appears that in practice the implementation has not yet promoted significant changes in the effective insertion into the labor market.

However, there are some achievements in the participation of deaf people in events in some countries. For instance, a guide for event professionals has been developed with numerous strategies for including the deaf in public meetings and events. The guide provides information such as registration, meeting points, visual communication, audiovisual equipment (caption and loop system), and tips for promoting the event (Australia, 2013). 


\section{METHODOLOGY}

The present study is based on the qualitative methodology of a descriptive and exploratory character. According to Prodanov and Freitas (2013), qualitative research allows the researcher to maintain direct contact with the study environment, demonstrating a greater number of existing characteristics of the observed object. While exploratory research is developed to provide an overview, get closer to a certain fact (GIL, 2008). In the context of this research, we approach the deaf and the event market as a means of work, this type of research is carried out especially when the chosen theme is little explored, and it is difficult to formulate precise hypotheses.

In the process of data collection, a questionnaire was sent by email in Word format, for producers of listening events, containing eleven closed questions and one open question, in order to promote the visibility of the deaf as a qualified employee for the sector of events. For the deaf, a form was sent on google forms, containing 16 objective questions and a video interpreted by a deaf, with the same questions in Libras. In addition to answering these questions through the form, the deaf recorded videos with their answers in Libras, their first language.

It is noteworthy that the questionnaire was adapted to the deaf language, to facilitate understanding and later the answers were transcribed by a translator/ interpreter, in order to identify whether this group has already worked in events and, at the same time, instigate in them the possibility of working in this sector. To support the analysis of the data of this research, the software IRAMUTEQ1 (Interface of R pour les Analyzes Multidimensionnelles de Textes et de Questionnaires) was used. The choice of this methodological tool allows different processing and statistical analysis of texts produced, among the advantages is that it is free in the logic of open source - open source. Through this software, it was possible to generate two contributions in the analysis of the speeches, the word cloud, and similarity, two formats in which the results stand out for their easy-to-understand visibility. Therefore, the analysis of the results was divided into two groups: the deaf and event producers.

\section{DISCUSSION AND RESULTS}

The following results will be presented by two groups: the deaf and event producers.

The first group: the deaf

As for the characterization of the profile of the deaf, the age range comprised from 21 to 28 years old, as for the academic formation the technical level predominated, between the medium and superior levels. Below is an analysis of the results of the deaf collected through a questionnaire applied in Libras, their first language, and through google forms.

Respondent 01 (R1) is twenty-one years old and lives in Gama/GO. R1 has taken the Portuguese course and at the present is unemployed. R1 attends sports events. R1 has never worked as a freelancer in events and has never participated in any recruitment process to work in events. The R1 has never worked and communicates with colleagues with difficulty. R1 would like to work in events.

Respondent 02, is twenty-eight years old, lives in Valparaíso / GO, has already taken a technical administrative level course. R2 is employed and goes to social events, has never worked as a freelancer in events. R2 did not participate in any selection process, nor did R2 do any training to work at events. R2 has already worked with image monitoring, has contact with a Libras translator/interpreter at work, can communicate easily with colleagues.R2 would like to work with events.

Respondent 03 (R3) is twenty-three years old and lives in Ceilândia/DF. R3 has already taken a technical administrative level course, and the status is employed. R3 has been participating in religious events and has never worked as a freelancer in any event. R3 has never participated in a recruitment process nor had any training to work in events. R3 has never worked but has a good and easy communication level with friends. R3 would like to work in events.

Respondent 04 (R4) is twenty-eight years old and lives in Taguatinga/DF. R4 has taken the Administration Assistance course as graduation. R4 had internship work at CODEPLAN. R4 enjoys social events. R4 has never worked as a freelancer in events and has never participated in a recruitment process. R4 has never taken any training to work in events. R4 has no access to the Sign Language translator at work and it has been hard to communicate with co-workers. R4 would like to work in events.

Respondent 05 (R5) is twenty-one years old and lives in Brasilia/DF. R5 has taken the Administration Technical High School level and status is employed. R5 has been enjoying social events but has never worked as a freelancer in events. R5 had some Sign Language interpreter contact on previous work experience. R5 can easily communicate with colleagues. R5 would like to work in events.

Respondent 06 (R6) is twenty-three years old and lives in Cidade Ocidental/GO. R6 has already taken a technical event course level and the current work status is unemployed. R6 has been participating in social events and has already worked in events as a freelancer for four or more hours. R6 has worked as a decorator and setter for events. R6 has no access to a Sign Language translator at work and can communicate with some 
difficulty with colleagues. R6 would like to work in

Table 01 - Characteristics of the profile of the interviewed deaf

\begin{tabular}{|c|l|l|l|}
\hline Interviewed & \multicolumn{1}{|c|}{ Age } & $\begin{array}{l}\text { Education Le- } \\
\text { vel }\end{array}$ & \multicolumn{1}{|c|}{ Location } \\
\hline Respondent 01 & $\begin{array}{l}21 \text { years } \\
\text { old }\end{array}$ & High School & Gama - GO \\
\hline Respondent 02 & $\begin{array}{l}28 \text { years } \\
\text { old }\end{array}$ & $\begin{array}{l}\text { Technical } \\
\text { High School }\end{array}$ & $\begin{array}{l}\text { Valparaíso - } \\
\text { GO }\end{array}$ \\
\hline Respondent 03 & $\begin{array}{l}23 \text { years } \\
\text { old }\end{array}$ & $\begin{array}{l}\text { Technical } \\
\text { High School }\end{array}$ & $\begin{array}{l}\text { Ceilândia - } \\
\text { DF }\end{array}$ \\
\hline Respondent 04 & $\begin{array}{l}28 \text { years } \\
\text { old }\end{array}$ & Graduated & $\begin{array}{l}\text { Taguatinga } \\
\text { - DF }\end{array}$ \\
\hline Respondent 05 & $\begin{array}{l}21 \text { years } \\
\text { old }\end{array}$ & $\begin{array}{l}\text { Technical } \\
\text { High School }\end{array}$ & Brasília- DF \\
\hline Respondent 06 & $\begin{array}{l}23 \text { years } \\
\text { old }\end{array}$ & $\begin{array}{l}\text { Technical } \\
\text { High School }\end{array}$ & $\begin{array}{l}\text { Cidade } \\
\text { Ocidental - } \\
\text { GO }\end{array}$ \\
\hline Respondent 07 & $\begin{array}{l}21 \text { years } \\
\text { old }\end{array}$ & Graduated & $\begin{array}{l}\text { Planaltina - } \\
\text { DF }\end{array}$ \\
\hline
\end{tabular}

events.

Respondent 07 (R7) is twenty-one years old and lives in Planaltina/DF. R7 has taken the advanced Sign Language course. Graduated level. R7 works on Tactic Operational 11 GTOP2/SUFISA3 SEMOB4 I and partici-

Source: Research authors (2019)

pates in social events. R7 has never worked as a freelancer in events and has never had any training to work in events either. R7 has no contact with any Sign Language interpreter at work, but can easily communicate with co-workers. R7 would not like to work in events.

Given this, there is an ease in communication between colleagues by most respondents, however, most do not have contact with Libras translator/interpreter, which creates some difficulty in communication. In this context, Santana (2007, p.26) states that "the difficulty of dealing with another type of language other than oral, makes the interlocutors of the deaf - including their parents - see themselves in a conflict situation, which prefer to get away. " Through this statement by the author in relation to the profile of the interviewees, it is evident that most of them reached the technical level, which demonstrates "respect for each other's autonomy and dignity is an ethical imperative and not a favor that we may or may not grant to each other" (FREIRE, 1996, p.25), thus suggesting that the capacity for development is individual and inherent to being, here there is a reflection both in the educational and professional spheres, which nevertheless also become an everyday learning environment.

\section{2nd Group: Event Producers}

As for the producers, they have been selected according to the plurality of performed events for each of them; the goal here is to have the most variety of event type possible, which has been demonstrated by the results.

As for the producers, they were selected according to the plurality of types of events held by each of them, in order to have the greatest possible variety of types of events, which stand out in their respective responses, which has been demonstrated by the following results. Producer 1 (P1) performs between ten to twenty events per year and hires from five to ten workers per event. From 2016 up to the current time, the P1 has hired one deaf for a sporting event, which has developed the logistic support successfully. The recruitment was accomplished by the recommendation of a business colleague. There was an easy interaction among coworkers. No training was offered. The worker performed during four or more hour-long events. The event type was sporting. In order to contribute to the research, the P1 comment was: "I could observe that the deaf are more focused and helpful for events. The hearing loss demands their eye contact attention all the time to the bosses and coworkers.

Producer 2 (P2) performs more than one hundred events per year and hires between ten to thirty workers per event. From 2016 up to the current time, the P2 has not used any deaf worker in his performances. The P2 has never hired any deaf worker. The events are four or more hours long. The event type is social. In order to contribute to the research, the P2 comment was "We have never thought about this possibility before, which is hiring people with loss hearing (deaf). I hope this could be faced as a good example to other companies". Producer 3 (P3) performs between one and ten events per year and hires between ten and thirty workers per event. From 2016 up to the current time, the P3 has not used any deaf worker in his performances. The P3 has never hired any deaf worker. The events are four or more hours long. The event types are social, cooperate, cultural, and entertainment. In order to contribute to the research, the P3 comment was "I have never hired a loss hearing worker before because I have no information on where to find these professionals. I have no restriction on aggregating those professionals to my events. It's just a lack of information!"

Producer 4 (P4) performs between one and ten events per year and hires between one and five workers per event. From 2016 up to the current time, the P4 has not used people with hearing disabilities in those events. The P4 has never hired any deaf worker. The events are four or more hours long. The event types are cultural and entertainment.

Producer 5 (P5) performs between thirty and one hundred events per year and hires between ten and thirty workers per event. From 2016 up to the current time, the P5 has not used any deaf worker on his performances. The P5 has never hired any deaf worker. The 
events are four or more hours long. The event type is social. In order to contribute to the research, the P5 comment was "I got very interested in this topic. I would like to have access to the research results and more information about hiring people with deaf disability."

Producer 6 (P6) performs between one and ten events per year and hires between one and five workers per event. From 2016 up to the current time, the P6 has not used any deaf worker in his performances. The P6 has never hired any deaf worker. The events are four or more hours long. The event types are social and corporate.

These testimonies expose to a reality not yet accessible in this market and lack of information. With the different types of events mentioned by the producers who responded to this research and with the variation in the number of employees hired by them, it appears that the space for access of deaf professionals in this specific niche is scarce, lacking only clearer information for both. It appears from the responses of these producers that there is a predisposition for placing these professionals on the market and an interest in knowing more about the subject.

For both respondent groups, some roles were presented that could be performed by the deaf in several event types, just as following: a master of ceremonies, a receptionist, a photographer, a decorator, accreditation, an assembler, a QR Code operator, logistic support, general services, image monitoring, administrative activities. It was pointed out that with a favorable work and training environment, these are functions that can be performed by deaf people with some or no adaptation.

Therefore, in the data analysis, the responses of the deaf were submitted to the Iramuteq software, which allows the processing of the frequency of words and the analysis of content through the responses of the producers. For that, we used the Iramuteq resource to analyze similarity, which allows the identification of occurrences between words and enables the connection between words and content analysis proposes to analyze the text to obtain information that allows us to make analysis on the content and make inferences. (Bardin, 1977).

Considering the cloud of words, the most commented were highlighted as follows: event, work, perform, deaf, hire, respondent, participate. As for types of words, the following ones were often used: coworker, communication, process, to inform, collaborator, easiness, hardness, contact, administrative, contribute, current. In addition, the word event was mentioned fifty-one times followed by the word work mentioned by twenty-seven times, as can be identified in graphic 1 .
The similarity analysis (figure 2) performed in the IRAMUTEQ software (LOUBERE; RATINAUD, 2014), based on the graph theory, brings possibilities to obtain cohesion between the words, cooperating to identify the structure shown by the terms. It was found that the respondents understood the questions and expressed their understandings about holding an event, working and providing access for deaf employees, also envisioning the possible functions that these professionals can perform within a given event.

With all obtained information, it was possible to evaluate the deaf perception of events and the working relationship under the Sign Language influence. In summary, the similarity graphic provides a relevant gathering of words to the exposed theme and at the same time presents the connection between those words (image 2):

In the analysis, the following connection between the most prominent words is perceived, assuming a central position in the axes in relation to the others: event, work, hiring, assuming roles of central words. The event was the central word, involving the largest number of words such as typology, perform, training, social, liking, ease, process, and others. Similar to a tree, we can compare the connection between words with the root of a tree, so we have more interconnected words such as: to achieve, to communicate, difficulty, among others, all of these based on the central word which is events.

This analysis highlights the central core of this research, which is events, as an opportune means for the deaf person to have new possibilities regarding work, in a segment of tourism that has a great growth perspective. It is observed that the interconnected secondary words, all cited by the respondents, can be considered points of interest and understanding for a satisfactory performance to the inclusion.

\section{CONCLUSIONS}

The researches studied as a reference for conducting this study on the employability of the deaf in the event market, clarify and suggest that communication is the great barrier imposed in a predominantly hearing society. There is also a strong indication that sign language should be inserted on the regular education curriculum, and in the work environment (workshop format for workers, for example) to narrow the disparity between 
deaf and hearing societies.

In a globalized world, where everyone is mentioned, the exclusion of many can still be caused by the lack of active participation in public policies, the inherent comfort and selfishness of human beings, and the lack of political will in our country, where the laws are not fully enforced.

\section{REFERENCES}

Associação Brasileira de Empresas de Eventos, ABEOC (2013). Retrieved June 23, 2019, from http://www.abeoc.org.br/wpcontent/uploads/2014/10/II-dimensionamento-setoreventos-abeocsebrae-171014.pdf.

Bardin, L. (1977). Análise de conteúdo. Edições 70, 1977.

Brasil. (2005). Decreto no 5.626/05. Accessed on April 10, 2019, http://www.libras.com.br/decreto-5626-de-2005.

Brasil. (2005). Decreto no 5.626/05, de dezembro de 2005. Accessed on April 10, 2019, http://www.libras.com.br/decreto5626-de-2005.

Brasil. (2002). Lei no 10.436, de abril de 2002. Accessed on April 10, 2019, http://www.planalto.gov.br/ccivil_03/leis/2002/ I10436.htm.

Brasil. (1991). Lei no 8.213/91, de 24 de julho de 1991. Accessed on April 12, 2019, http://www.planalto.gov.br/ccivil_03/ leis/I8213cons.htm.

Carvalho, R.P.Q. (2012). O Surdo e o Mercado de Trabalho: Conquistas e desafios. Revista Caleidoscópio, V. 1, n. 4.

Freire, P. (1996). Pedagogia da autonomia: Saberes necessários à prática educativa. Paz e Terra.

Gesser, A. (2009). LIBRAS? Que língua é essa? Crenças e preconceitos em torno da língua de sinais e da realidade surda. Parábola Editorial.

Giacaglia, M.C. (2006). Organização de eventos: Teoria e prática. Thomson Learning.

Gil, A.C. (2008). Métodos e técnicas de pesquisa social (6th ed.). Atlas.

Goss, B. (2003). Hearing from the Deaf Culture. Intercultural Communication Studies XII-2. New Mexico State University.

Ibge. (2010) Censo demográfico (Brasil). Accessed on May 12 2019, pesquisa/23/23612

Ministério do Turismo. (2019). Congresso do setor de eventos. Accessed on June 16, 2019, http://www.turismo.gov.br/\% C3\%BAltimas-not\%C3\%ADcias/12595-turismo-apresentaa\%C3\%A7\%C3\%B5es-em-congresso-do-setor-deeventos.html
Oliveira, T.F. (2019). Inclusão de pessoas com necessidades especiais no mercado de trabalho. Accessed on February 20, 2019 www.webartigos.com/articles/1126/1/inclusão-depessoas-com-necessidades-especiais-no-mercado de trabaIho/pagina1.html

Novaes, E. C. (2010). Surdos: Educação, direito e cidadania. Wak. Graphic 1: Iramutec cloud of words

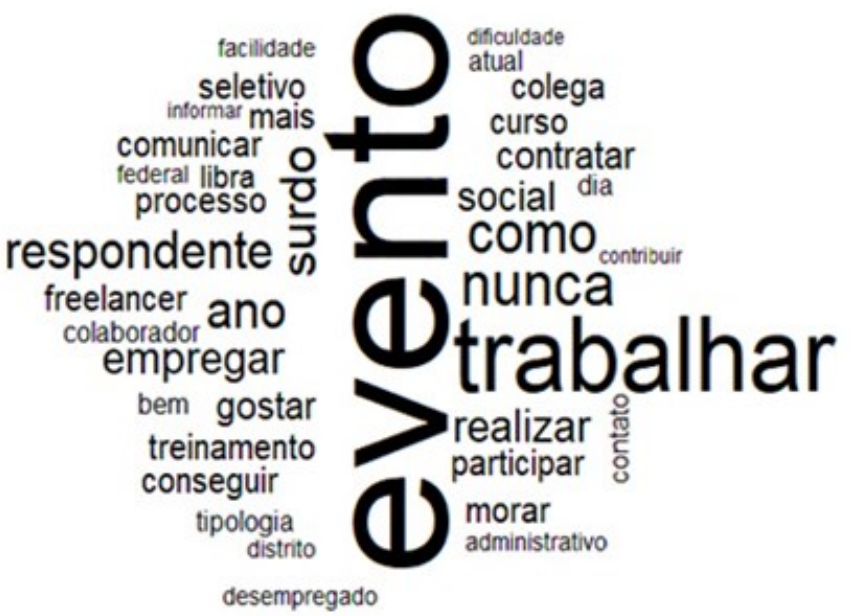

Source: Iramutec operated by the authors (2019).

Prodanov, C. C. (2013). Metodologia do trabalho científico [recurso eletrônico] : métodos e técnicas da pesquisa e do trabalho acadêmico (2nd ed.). Feevale.

Pastore, J. (2000). Oportunidades de trabalho para portadores de deficiência. Editora Ltr.

de Quadros, R. M., Karnopp, L. (2004). Língua de sinais brasileira: Estudos lingüísticos. Porto Artmed.

Ratinaud, P. (2009). IRAMUTEQ: Interface de R pour lesAnalyses Multidimensionnelles de Textes et de Questionnaires (Computer software).Accessed on June 02, 2019, http:// www.iramuteq.org.

Santana, A.P. (2007). Surdez e Linguagem. Plexus.

Senac, D. N. (2000). Eventos: Oportunidades de novos negócios. Editora Senac Nacional.

Strobel, K. L. (2008). Surdos: Vestígios Culturais não Registrados na História. Tese de Doutorado em Educação - UFSC - Universidade Federal de Santa Catarina.

Zitta, C. (2009). Organização de Eventos: Da ideia à realidade. Editora Senac/DF.

Accessed on June 16, 2019, http://www.turismo.gov.br/\%C3\% BAltimas-not\%C3\%ADcias/12595-turismo-apresenta-a\% C3\%A7\%C3\%B5es-em-congresso-do-setor-de-eventos.html

Oliveira, T.F. (2019). Inclusão de pessoas com necessidades especiais no mercado de trabalho. Accessed on February 20, 2019 www.webartigos.com/articles/1126/1/inclusão-depessoas-com-necessidades-especiais-no-mercado de traba- 
Graphic 1: Iramutec cloud of words

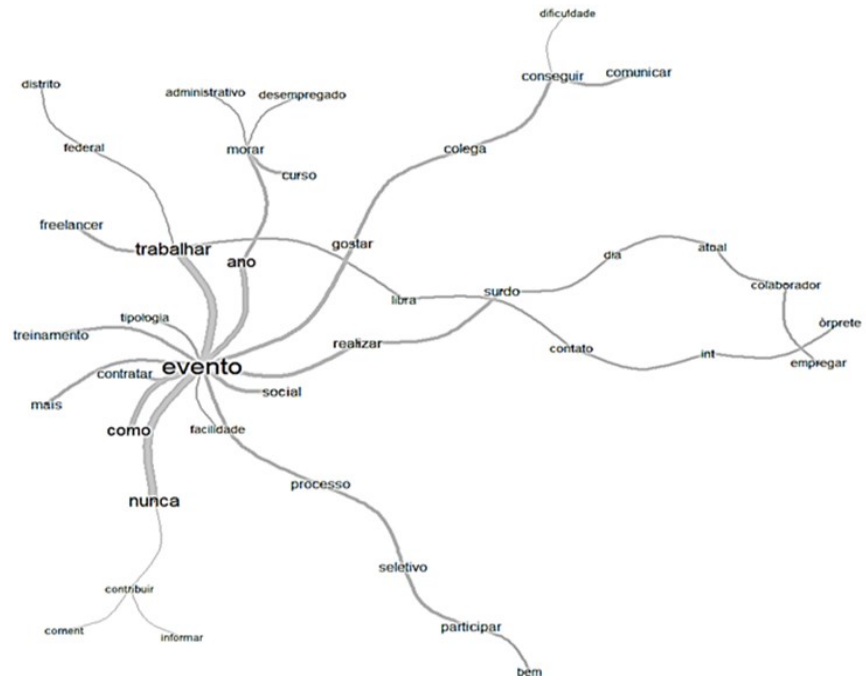

Source: Iramutec operated by the authors (2019).

Iho/pagina1.html

Novaes, E. C. (2010). Surdos: Educação, direito e cidadania. Wak.

Prodanov, C. C. (2013). Metodologia do trabalho científico [recurso eletrônico] : métodos e técnicas da pesquisa e do trabalho acadêmico ( 2 nd ed.). Feevale.

Pastore, J. (2000). Oportunidades de trabalho para portadores de deficiência. Editora Ltr.

de Quadros, R. M., Karnopp, L. (2004). Língua de sinais brasileira: Estudos lingüísticos. Porto Artmed.

Ratinaud, P. (2009). IRAMUTEQ: Interface de R pour lesAnalyses Multidimensionnelles de Textes et de Questionnaires (Computer software).Accessed on June 02, 2019, http:// www.iramuteq.org.

Santana, A.P. (2007). Surdez e Linguagem. Plexus.

Senac, D. N. (2000). Eventos: Oportunidades de novos negócios. Editora Senac Nacional.

Strobel, K. L. (2008). Surdos: Vestígios Culturais não Registrados na História. Tese de Doutorado em Educação - UFSC - Universidade Federal de Santa Catarina.

Zitta, C. (2009). Organização de Eventos: Da ideia à realidade. Editora Senac/DF. 
